History of Photography

\title{
Three generations of grass
}

\section{Kate Sampsell}

To cite this article: Kate Sampsell (2003) Three generations of grass, History of Photography, 27:4, 333-341, DOI: 10.1080/03087298.2003.10441268

To link to this article: https://doi.org/10.1080/03087298.2003.10441268

央 Published online: 19 Jan 2015.

Submit your article to this journal

山 Article views: 35

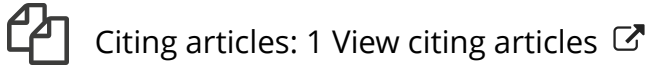




\title{
'Three Generations of Grass'
}

\section{Photography, Liberalism and the Myth of the American Yeoman}

\author{
Kate Sampsell
}

The 'American Dream' briefly changed character in the decade of the Great Depression. Shifting from a belief grounded in the frontier myth and the mystical power of the yeoman farmer to one that expressed the cooperative ideal, millions of Americans reevaluated their commitment to rugged individualism, an ideology that had dominated the decade of 1920s. Social documentary photography played an important role in that transformation. I believe that describing this change is another way to interpret the phenomenon described by Michael Denning in The Cultural Front as 'the laboring of American culture'. The thesis underlying this revisit to the American Dream is that there has been a sibling rivalry in the history of American ideas: the struggle for the definition of what is 'American' has fluctuated between a basis in cooperation and in competition. The history of this rivalry is manifest in a wide range of intellectual histories and debates, including Daniel Rodgers's 'Republicanism: the career of a concept', which examines the swing between libertarianism and egalitarianism in American historiography. The tension between the collective and the private, the whole and the one, the right and the duty-the greatest good for the greatest number versus individual license-is an old one in American history. ${ }^{2}$

Daniel Rodgers charts in his landmark essay an intellectual paradigm shift. ${ }^{3}$ According to Rodgers, American historiography underwent an intellectual realignment in the period of the Great Depression and World War II. Rodgers does not identify a specific event or catalyst in the Depression as initiating the change. However, he does place the shift as occurring from the pre-Depression Charles Beard economic analysis of American history to the post-World War II Louis Hartz ideology, which located John Locke's 'liberal' version of freedom at the centre of the revised American canon. ${ }^{4}$ Rodgers does not substantively analyse the reasons for the shift to new core ideas. I argue here that the history of how the Resettlement Administration/Farm Security Administration/Office of War Information (hereafter RA/FSA/OWI) archive at the Library of Congress came to be and what it came to represent-although not responsible for the structural shift in historiography - came to play a substantial role in the changed mythology of US history discussed by Rodgers. This was in turn integral to the ideological triumph of Lockean individualism after World War II.

I posit that the ideological shift described by Rodgers was not atypical in American history. It was part of a greater meta-philosophical dialectic endemic to US politics, society and culture. The pendulum's course is visible throughout American history. From the Articles of Confederation to the Constitution, from Reconstruction to the Gilded Age, from Progressivism to the 'white-collar paradise' of the $1920 \mathrm{~s}$, dramatic changes seem to have been fueled by a cycle of reaction and redemption. Fundamentally, definitions of American liberty are the cause for oscillation: whether American liberty is negative or positive, libertarian or egalitarian. This is the central dialectic of American intellectual history.

We can look at any given period in American history and see the tension between negative and positive liberty. For example, a new understanding of American history emerged for the 1930s intellectual generation. Based on the idea of a usable past - Van Wyck Brooks's call for observation rather than assumption as the basis for history-that generation examined history in terms of the needs of the working classes. ${ }^{5}$ One way to describe the political and cultural climate of the 1930 s is to explain it as a moment in time when the liberal/republican pendulum had reached its republican-or egalitarian-zenith, only to be pulled back in the other direction in a post-World War II climate of suspicion.

The usable past thesis was a practical tool in the hands of 1930 s intellectuals and artists. It is visible in the ideas of those responsible for creating, maintaining, guiding and preserving the FSA archive. The political and economic philosophy of Columbia economist Rex Tugwell merged with the dedication to the Beard analysis of history preserved in the textbooks and teaching outlines of 
Columbia historian Harry Carman. Together, they educated graduate student Roy Stryker, who was then inspired by them to create a body of carefully selected and commissioned photographs - primary sources for the use of future historians, a file that reflected his and his collaborators' view of the present. He attempted to create what he and Tugwell deemed 'a sourcebook of American history'. Their desire was to provide an archive of the present to be accessed by future historians. Intentionally crafting a past is an endeavor that seems destined to fail for any wider purpose than being an intellectual biography of the one who compiles it. Nonetheless, Stryker's good fortune and true skill-his ability to recognize greatness in and recruit skilled photographic artists-insured that this attempt at manipulating future history actually succeeded, even though future historians who used his archive did not necessarily find any of the same truths that Stryker intended to convey. ${ }^{6}$ This 'sourcebook' became what is known as the FSA archive at the Library of Congress. Although the record does not reflect it, one can imagine that the branch charged with collecting the present as an archive of the past was named the Historical Section for that reason.

The archive as collected and as intentionally preserved represented a specific view of the present. Remember that Stryker crafted shooting scripts, 'killed' (by putting a spike through the centre of the negative), by his own account, nearly 100000 negatives, refused to hire Lewis Hine, a photographer who had himself constructed history, transferred the archive to the Library of Congress for safekeeping, and advocated a permanent agency in government to produce and maintain an edited picture archive for historians. Stryker's view was informed by his own understanding of American history coloured by his and his contemporaries' historical world-view: the Beardian paradigm. ${ }^{7}$ And although Stryker's view of history was quite shallow, throughout his career he attempted to please his mentor, Rex Tugwell. ${ }^{8}$ Stryker's dedication to Tugwell is reflected in the collection.

For the substance of his sourcebook, Stryker, selfdefined as Tugwell's 'fair-haired boy', did not promote a new analytic direction in American history; nor did he encourage the writing of all US history from the point of view of agriculture- 'farming' the master narrative, so to speak. ${ }^{9}$ Rather, his history was a narrative view of rural America, simple visual documentation and storytelling important to him only because of the long history of the USA as an agrarian nation and his own experience growing up in rural Colorado. Stryker's horizons were limited, but his archive- thanks largely to the work of the superlative photographers who worked for him - provided an opportunity for more expansive thinkers to find the farm as the soul of America, even in the post-machine-age middle part of the twentieth century. ${ }^{10}$ Yet, Stryker's achievement, harmless and mainstream as it was in concept and magnificent as it was in exccution, added fuel to the reactionary fire that erupted after the death of Franklin
D. Roosevelt in 1945. The RA/FSA archive became an influential and undeniable reservoir of the Beardian view of history, both because of Stryker's intent and because of the political agenda of Cultural Front RA/FSA photographers, most notably Dorothea Lange, Ben Shahn, Marion PostWolcott, and Arthur Rothstein. As a tangible reservoir of Beard, it proved to be an accelerant to the fires of postwar anti-communist paranoia.

One must try to understand Roy Stryker's doctrinaire and one-dimensional view of the world. The fact that the Historical Section was intended as a sourcebook of history influenced the decisions Stryker made regarding shooting scripts and which negatives were to be saved or 'killed'. Even Walker Evans's photographs made on the Let Us Now Praise Famous Men trip in 1936 were subject to the spike (figure 1). The very existence of the file, its preeminent place in American memory, its popularity, and the fact that it survived as an artifact from the culturally democratic 1930s could not help but play upon the forces that created Rodgers's explanation of postwar paradigm shift. ${ }^{11}$

Although the photography archive itself did not inspire a reactionary revolution, the use to which it was put in the wider culture certainly reinforced an economic view of American history and suggested an uprising against ownership, especially of land, even more radical than Beard or his followers ever advocated publicly. The photographs were not political tracts. Nevertheless, few viewers then or now could honestly look at the iconic 'Migrant mother' or any number of other faces and not come to conclusions similar to those of poet Archibald MacLeish, social documentarian Dorothea Lange, and filmmaker Pare Lorenz - that freedom and human dignity are not consistent with the unregulated private ownership of land and its inherent right of total exploitation. Conservatives attacked the photographs as communist propaganda. The backlash against the Cultural Front and its questioning whether capitalism was consistent with American ideals was fuel for the structural realignment. Photographs certainly reinforced that analysis eloquently and incontrovertibly. If nothing else, the images were the substance of a highly visible argument supporting the ruling idea of the egalitarian New Deal, a cooperative, positive-liberty analysis of history and American liberty; that is what they had been designed to do.

\section{A soundtrack to a visual poem}

The realities of the Great Depression distorted for many the concept of American liberty, especially for those who worked the land. The myth of American yeomanry was exposed in that decade. Although not quite a revolution, this subtle leitmotif in the 1930s social documentary aesthetic reflects perhaps the most fundamental change that the Great Depression authored in the intellectual life of America: the swing from the liberal view to the republican one, from rugged individualism to egalitarianism. Until 


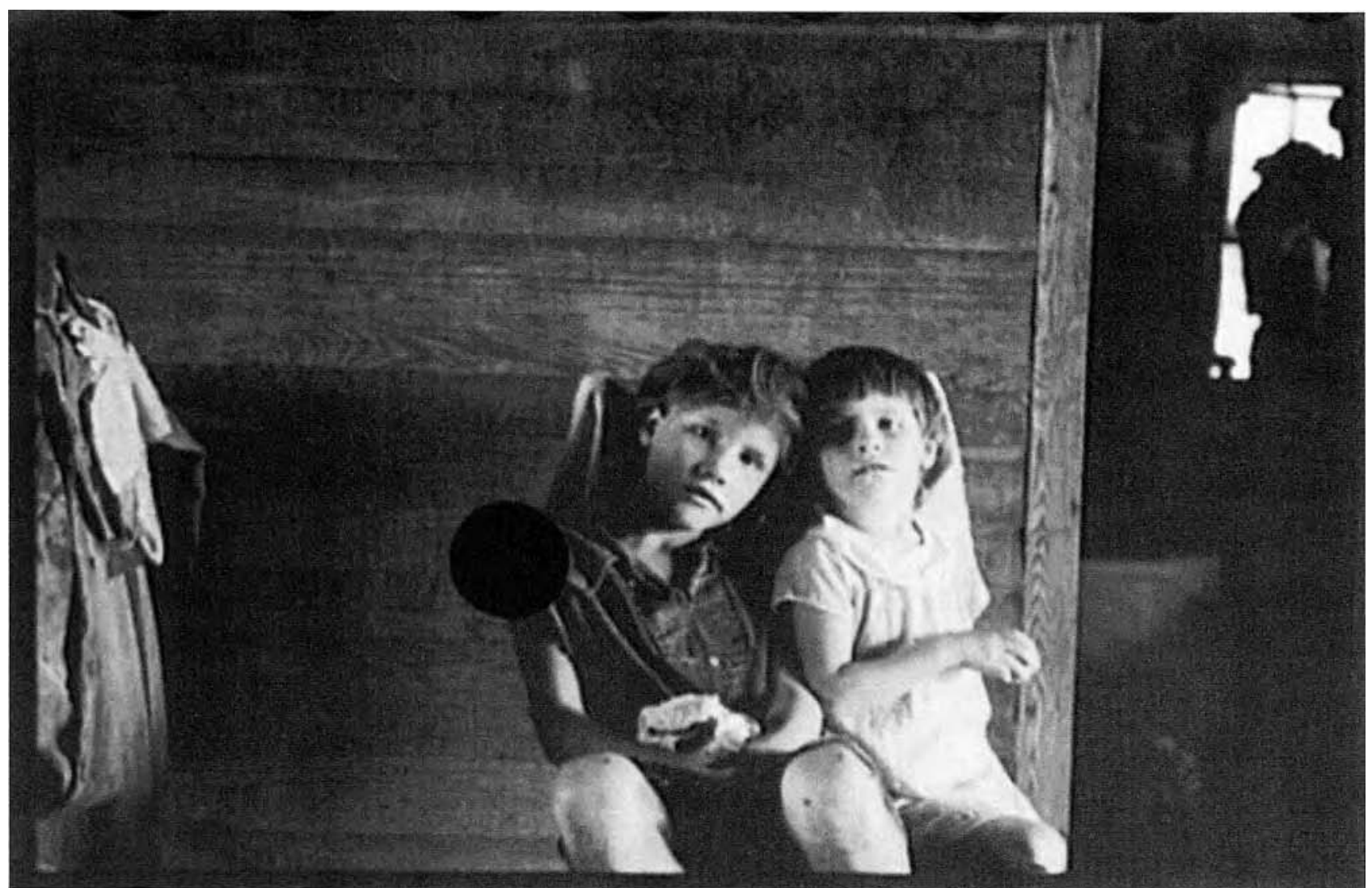

Figure 1. Walker Evans, Untitled, silver gelatin print from a killed negative, made by Evans on the Let Us Nou Praise Famous Men trip with James Agee, 1936. Courtesy of the Library of Congress, Washington, D.C.

the Great Depression, the myth of the yeoman was the mainstay of the American definition of liberty. ${ }^{12}$ Dorothea Lange and Paul Taylor addressed the issue directly in $A n$ American Exodus: A Record of Human Erosion. ${ }^{13}$ A subtext to this book was the disfranchisement that happened due to a modern-day enclosure movement, the converting of many small, single-owner farms into a few large, industrial, single-owner farms disqualified many from voting. Lange and Taylor directly connected the agitation found in 'The Beginnings of Organization' in the 1930s to the debates over suffrage held in 1787 (figure 2). ${ }^{14}$ By commenting on the removals - the human erosion - and the fact of the then recently revisited poll tax, they equated economic liberty to political liberty.

Furthermore, the 'go west, young man' advice of Horace Greeley constructed a view of the US West as a land of opportunity in the nineteenth century that was not seriously challenged until the Great Depression. ${ }^{15}$ Photographs of the economic and environmental impact of three generations of white settlement documented and accelerated the explosion of that myth, which in turn created the need for a new American mythology. It is possible to investigate how photography that documented the internal American diasporas and the aesthetic that they engendered suffused the culture of the Depression decade and became an operative force-both positive and negative-within Rodgers's succession of models. It is my view that photography was first a major means by which the culture became suffused and a new ruling idea disseminated. One did not need to be literate to understand a photograph. Second, photography provided strong evidence that cherished historical beliefs were, in substance, merely myth and not history. Third, photography was a medium through which a new mythology was built. It made possible the mass proliferation of a new understanding of history re-centred away from presidents, generals and industrialists. There is an extant example of how photography operated within the greater paradigmatic rcalignment: there is an artefact that stands as a clear expression of the relationship between photography and one American poet's understanding of his own intellectual history.

In Land of the Free, his poem 'narrating' a book of photographs, Archibald MacLeish searched for the source of American mythic liberty and found a tautology. He lamented: 'We told ourselves we were free because we were free. We were free because we were that kind. We were Americans'. He went on to connect the source of mythic liberty to the land: "Maybe we thought because the land went on/Liberty went with the land. ${ }^{16}$ In the mythology of American liberty, land and freedom have been incxtricably entwined. So long as there was land to be put under plow, American liberty could be ensured. From Thomas Jefferson's ideal of each yeoman farmer-citizen enfranchised to command the republic to the closing of the American frontier in Frederick Jackson Turner's much-debated thesis, the land and American liberty have 


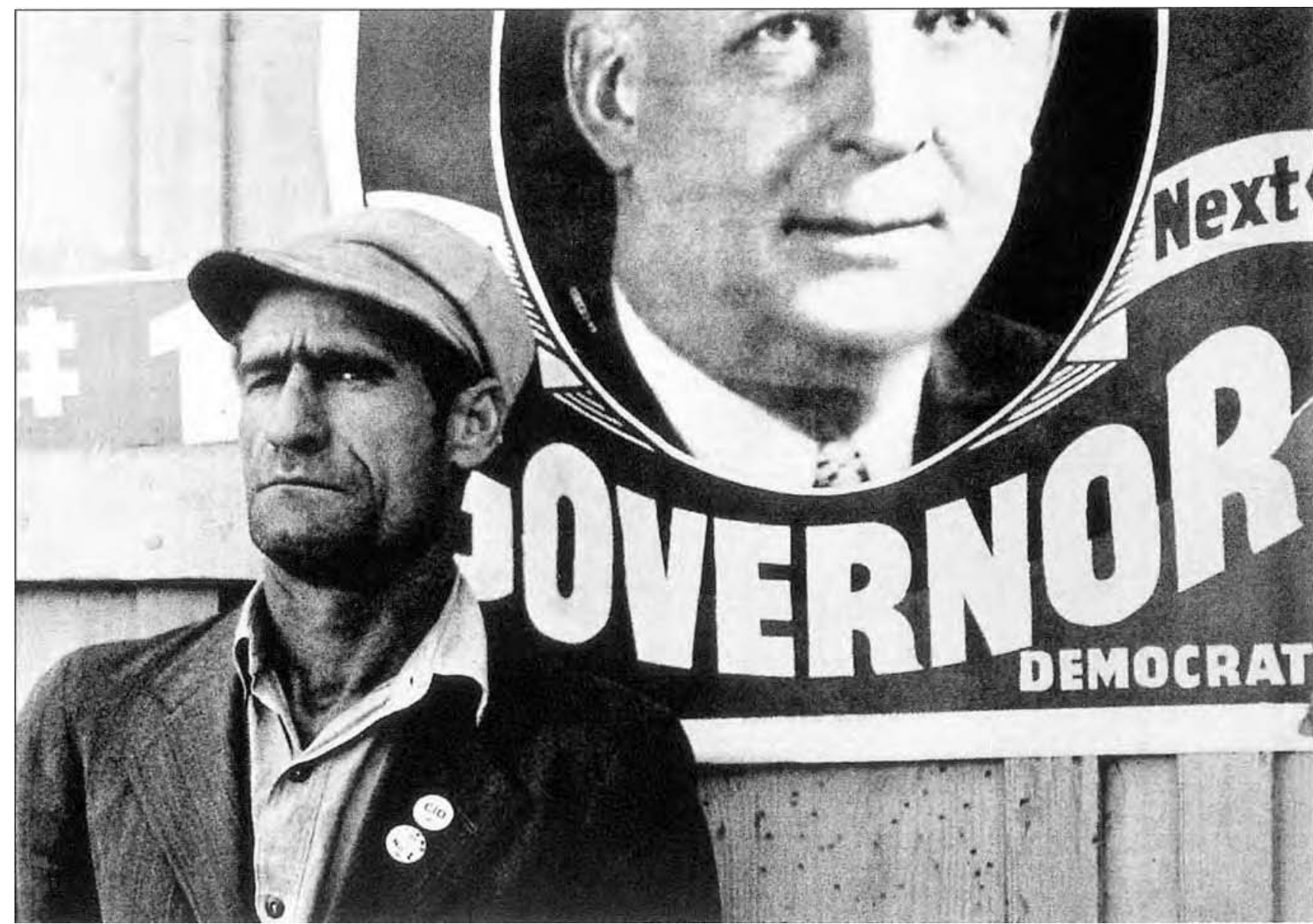

Kern County. November 1938

1787: Debate in the Constitutional Convention on limiting the Right of Suffrage to Freeholders

"There is no right of which the people are more jealous than that of suffrage."-Pierce Butler, Delegate from South Carolina

"We ought to attend to the rights of every class of people. [I have] often wondered at the indifference of the superior classes of society to this dictate of humanity and policy, considering that, however affluent their circumstances, or elevated their situations might be, the course of a few years not only might, but certainly would, distribute their posterity throughout the lowest classes of society. Every selfish motive, therefore, every family attachment, ought to recommend such a system of policy as would provide no less carefully for the right and happiness of the lowest, than of the highest, order of citizens."-George Mason, Delegate from Virginia

Figure 2. Dorothea Lange, Kern County, November 1938, silver gelatin print, 1938. Text Dorothea Lange and Paul Taylor, An American Exodus: A Record of Human Erosion, 1939. Copyright the Dorothea Lange Collection, Oakland Museum of California, City of Oakland. Gift of Paul S. Taylor. 


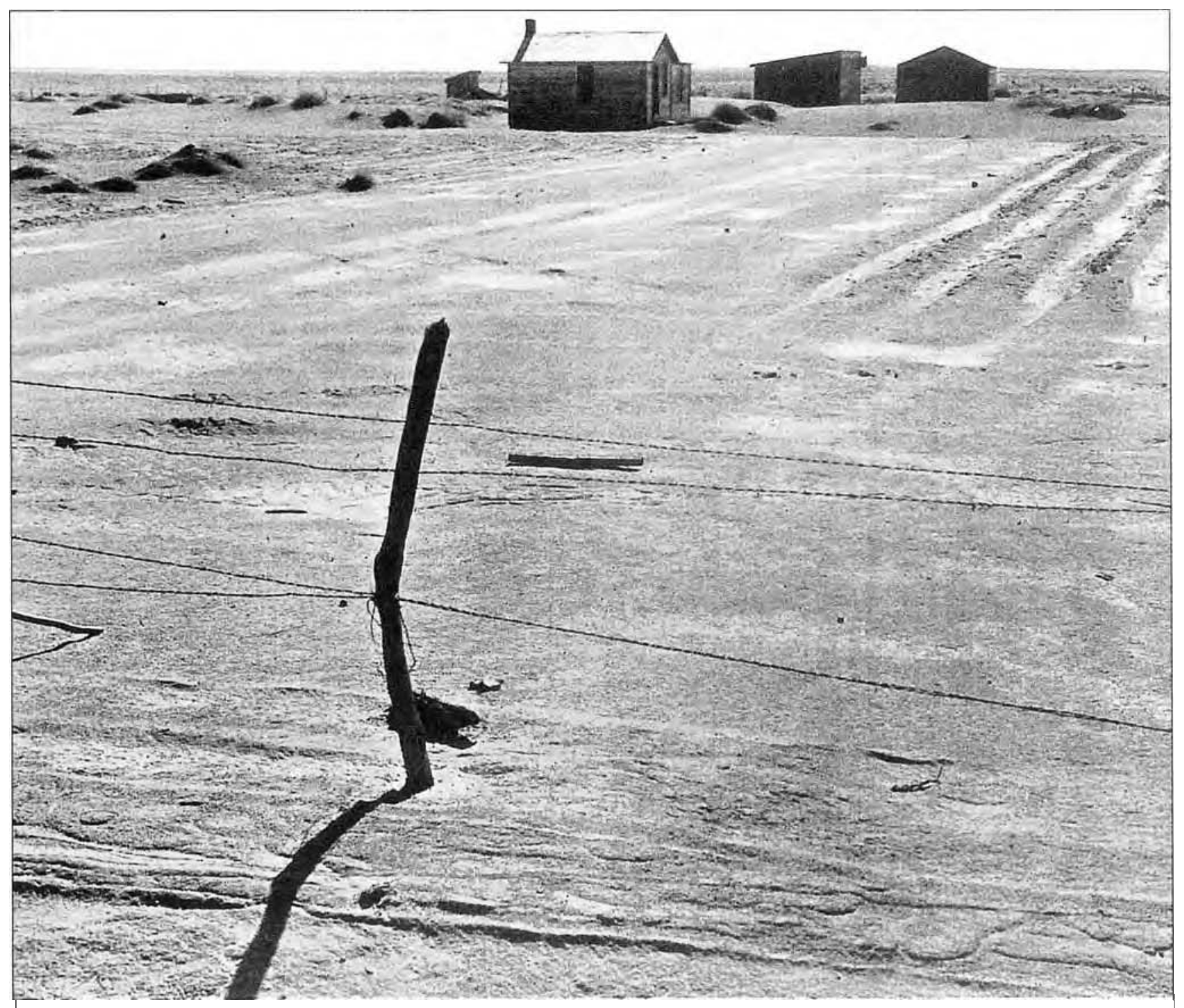

1938- “Top O' the World” Farm and Dairy Lands 13 Years After

"Lots.of 'em toughed it through until this year."

Coldwater. June 1938

Figure 3. Dorothea Lange, "TOP O' THE WORLD FARM" AND DAIRY LANDS 13 YEARS AFTER, silver gelatin print, 1938. Text Dorothea Lange and Paul Taylor, An American Exodus: A Record of Human Erosion, 1939. Copyright the Dorothea Lange Collection, Oakland Museum of California, City of Oakland. Gift of Paul S. Taylor. 
travelled hand in hand. The land-centred ideal continued into the twenticth century and (up to the present) in the guise of the American Dream of ownership. ${ }^{17}$

In the environmental, economic and human disaster that we call the Dust Bowl, the land failed Americans. American ingenuity and hard work were no longer sufficient to coax life from the soil. ${ }^{18}$ Because it was centred on negative liberty - freedom to be left alone to sink or swim on one's own merits - the American Dream became as endangered as the soil that turned to sand (figure 3).

During the Dust Bowl, no matter how much hard work, dedication and faith were expended, life could not be coaxed from what was rapidly becoming a desert. If hard work was the currency of the American Dream and hard work had become irrelevant, the cultural facts of the Dream itself came into question. With the Dream so threatened, many began to question the ethic of individualism and the myth that land was the sole source of American liberty. Surely, American liberty ran deeper than topsoil.

Instead of suggesting a 'new' frontier, thereby extending the old mythology and ratifying unsuccessful strategies for dealing with cultural stress (and implying a tacit acceptance of the appropriateness of treating the land as something to be 'conquered'), MacLeish suggested that the very concept of a frontier- 'frontierism' - should be abandoned. Intellectually similar to calling for an abandonment of structuralism, MacLeish rejected entirely the concept that liberty emanated from the land. Land of the Free can therefore be read as suggesting a paradigm shift in its own right-one more in line with Rex Tugwell's 1935 view of agriculture as expounded in The Battle for Democracy, his book defending the Agricultural Adjustment Act, than with Henry Wallace's 1934 justification of the same legislation New Frontiers.

To steer the national mind in a new direction meant changing the national mythology. A new view of history had to be written. Working in consort, but not collaborating, Dorothea Lange's (and the FSA's) photographs afforded MacLeish the opportunity to construct a document intended to do that: to provide a new basis, one other than land, as the intellectual underpinning of Americans' cherished liberty. MacLeish, putative poet-laureate of the Cultural Front and arch-defender of free speech, incontrovertibly linked democracy, freedom and the land in the nation's memory of the American yeoman. Simultaneously, however, he questioned whether that memory was as insubstantial as myth, and he asked if it could be replaced with something else, 'Or if there's liberty a man can mean that's/Men: not land' (figure 4). ${ }^{19}$

What MacLeish did in Land of the Free was twofold. He resituated the source of American liberty from individual ownership of land to association between people, and simultaneously he questioned what was meant by that liberty. The Louis Hartz, John Locke version of liberty that was embraced in the post-war, New Left period was nothing new in 1955. The usable past had been designed by Van Wyck Brooks in 1918 to confront a type of history that relied on mythology, and the substance of that mythology was, in the 1920 s, also the John Locke version of American freedom: liberalism, negative liberty and freedom from interference, not freedom to be equal. MacLeish alluded to that traditional understanding of American history and its inflexibility, its tendency to indoctrinate, to reinforce the message that the rights of the rich to their wealth were 'earned' by them through their 'talent' and their own hard work rather than inheritance and privilege. And, he criticized the teaching of orthodoxy that emphasized the politics of a landed aristocracy and omitted the ideas of truly revolutionary American egalitarian thinkers like Thomas Paine, James Otis, Nathaniel Bacon, and Daniel Shays. ${ }^{20}$

\section{'Three generations of grass'}

Rodgers is correct in thinking that liberalism was the victor in the post-war world, but he neglects the ideas expressed before World War II in tracts such as Land of the Free and those of other non-Marxist, homegrown radical intellectuals who shared MacLeish's vision. Not an economic view of history, through poetry and his selection of photographs MacLeish located the impulse toward freedom in personal cooperation, not ownership and exploitation. Yet his work, despite accusation, is not communistic. His ideas, like the ideas of many in his intellectual generation, based liberty on a solid American tradition, the cooperative commonwealth; he, like others, simply looked to other American Revolutionaries for his sentiments rather than the conservative, Lockean, individualists. Yet, the point of view expressed in Land of the Free was not Beardian either-in a sense, MacLeish's composition was opposed to structuralism, or at least the structuralism that pivoted on a fulcrum of private property.

The fact that MacLeish, inspired by the work of the FSA, re-located the source of freedom to 'men, not land' inspires a logical conclusion. Humans create and support governments and economies, and so such institutions should serve a greater number, not a select few. Such conclusions were the substance of what moneyed interests feared from the FSA. Furthermore, the voice in which MacLeish spoke was organic; he described one nation-created culturally by being willed into existence, unified in disaster, expressed in art-not just any one region affected by enclosure, drought or exodus. ${ }^{21}$ And, as in the poetry of William Carlos Williams, a national consciousness cannot be created without a preceding national vocabulary. Photographs provided the vocabulary for MacLeish and others who used the FSA archive as a sourcebook.

A clear, summary statement of MacLeish's message can be found on a page facing a Ben Shahn image made for the Resettlement Administration, 'Girl in a Louisiana home' (figure 5). The text reads: 


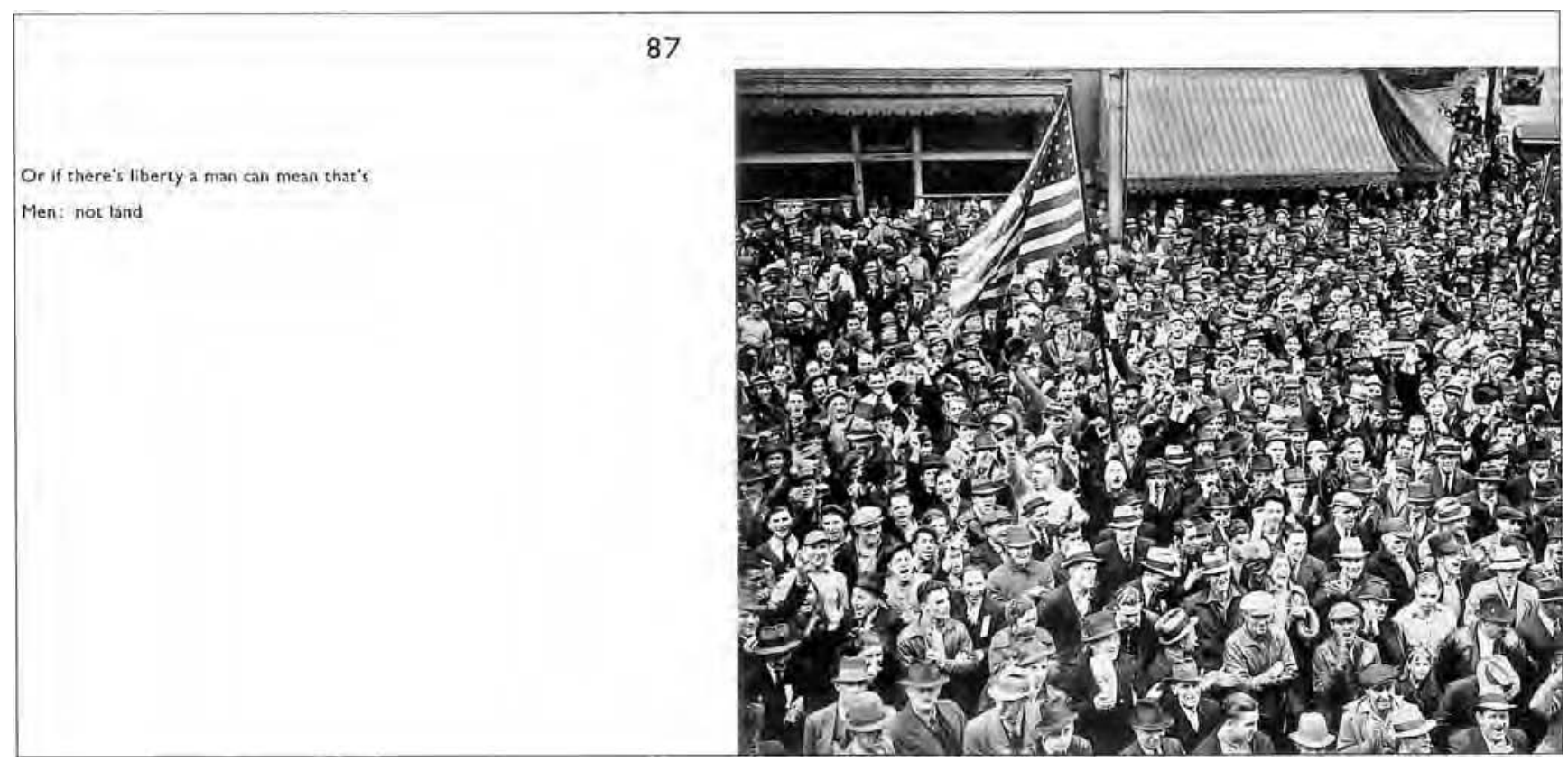

Figure 4. Unidentified Photographer, Pictures Inc., Celebrating the end of a steel strike in Pennsylvania, before1938. Text by Archibald MacLeish, Land of the Free, 1938. Courtesy of the Dorothea Lange Collection, Oakland Museum of California. Gift of Paul S. Taylor.

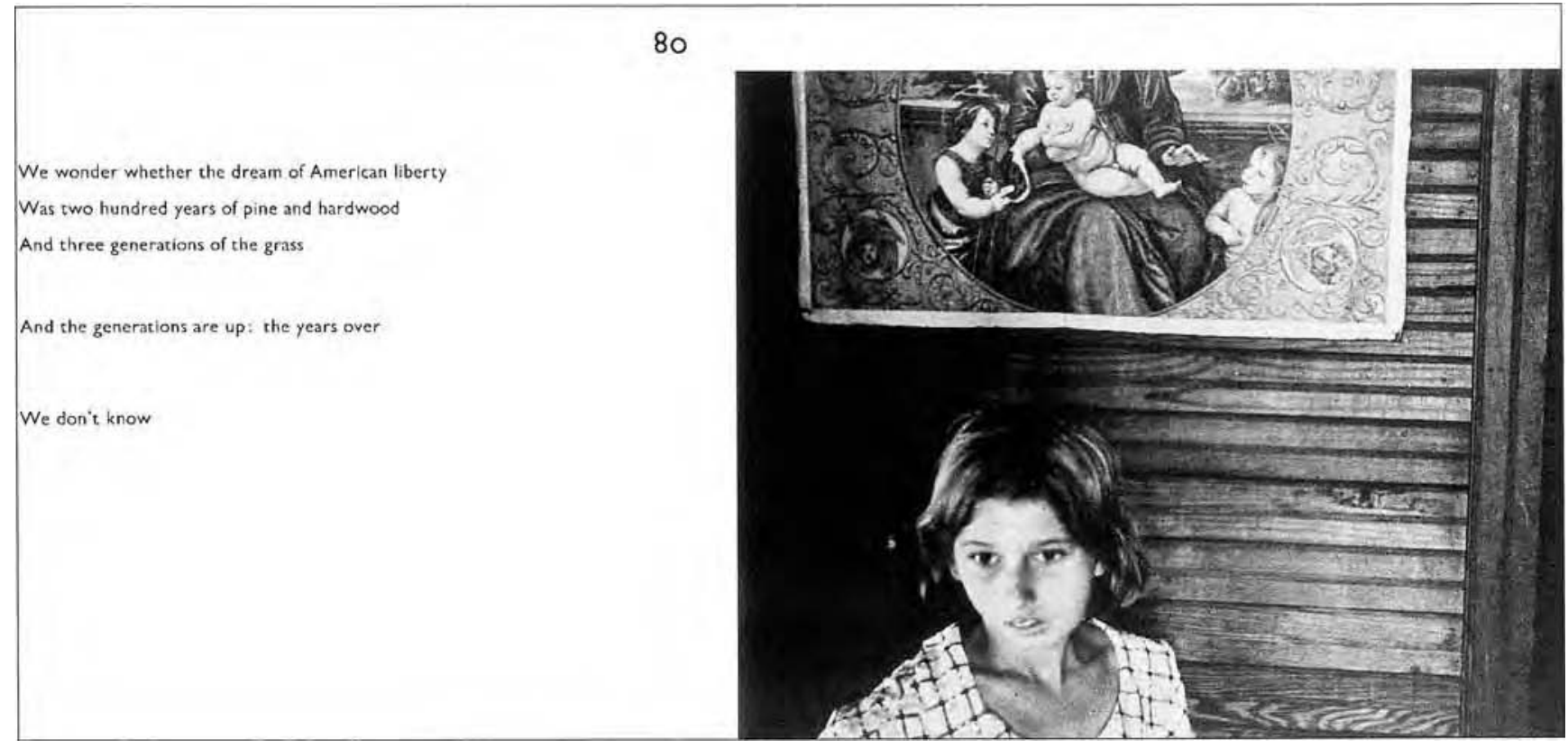

Figure 5. Ben Shahn, Girl in a Louisiana Home, also known as Child of Fortuna Family, Hammond, Louisiana, silver gelatin print, 1935. Text by Archibald MacLeish, Land of the Free, 1938. Courtesy of the Dorothea Lange Collection, Oakland Museum of California. Gift of Paul S. Taylor.

We wonder whether the dream of American liberty Was two hundred years of pine and hardwood And three generations of the grass

And the generations are up: the years over We don't know ...

We wonder if the great American dream

Was the singing of the locusts out of the grass to the west and the

West is behind us now:
The west wind's away from us

We wonder if the liberty is done: The dreaming is finished

We can't say

We aren't sure. ${ }^{22}$

Here MacLeish, with Shahn's image, questioned the fundamental nature of American liberty. Was America as an idea as finite as exploitable natural resources that, 
untended, could be exhausted? Did the American Dream of liberty extend only as deep as the topsoil? Could the ethic of personal freedom enjoy such a short reign in world history, be so fragile as to be defined solely by what could be coaxed from an exhausted earth? The implication in MacLeish's questions suggests to those who would peg liberty to the usefulness of the land-i.e. to mythic self-sufficiency-that liberty was a finite thing. MacLeish's land of the free would not die with the grass, fall with the hardwood, or blow away with the topsoil, or even leave with the Okie; freedom was not coterminous with wealth. Rather than solving the riddle of the American sphinx, MacLeish's New England voice simply served to remind that one species of the American tree of liberty was sown in poor soil, and therefore poor soil could not kill it.

The land, the yeoman, the agricultural dream: none could be divorced from Americans' understanding of democracy. And the face of the nation's suffering in the 1930s, thanks to Rex Tugwell, Roy Stryker and the FSA, was the face of the American farmer, tenant, "cropper, or yeoman, thrown off the land and facing starvation. The national narrative was an agricultural story; its end has yet to be written. And, although they tried, the social documentarians were largely ineffective in creating a permanent national mythology of cooperation to replace the old rugged individualistic pantheon, but they succeeded to the point where they frightened political and economic conservatives. And, they did, for a short while, touch the soul of a nation with the faces of its farmers, and they reminded them that, rightly or wrongly, the heart of their nation was its land. ${ }^{23}$

\section{Notes}

1. See Michael Denning, The Cultural Front: The Laboring of American Culture in the Tiventieth Century London: Verso 1997. See especially Denning's introduction, xvi-xvii, in which he gives five definitions of why his 'age of the CIO' (1935-1955) was a 'labored' American culture.

2. Daniel T. Rodgers, 'Republicanism: the career of a concept', Journal of American History 79 (June 1992), 11-38.

3. See Thomas Kuhn, The Structure of Scientific Revolutions Chicago: Univ. of Chicago Press 1996.

4. Charles Beard's economic study of US history, a point of view that analyses major events in US history as having been driven by economic rather than the more familiar liberal/democratic ideological rhetoric can be considered a forerunner in the same intellectual tradition as Howard Zinn's revisionist, A People's History of the United States New York: HarperCollins 1980). The American National Biography Online adequately describes Louis Hartz's most celebrated work, The Liberal Tradition in America (1955):

Despite America's boasted pluralism, Hartz argued, political conflict has always been confined by a parochial outlook, which he termed 'liberalism". By that he meant a commitment in economic matters to capitalism and in politics to democracy. His device to bring out these limitations was the contrast with the far wider possibilities of politics revealed by comparison with Europe. There liberalism also flourished, but also in interaction and competition with socialism on its Left and a true conservatism on its Right. (emphasis added, http://wuw.anb.org/articles/14/14-01127-article.html)

Although Hartz criticized America's 'parochialism', Rodgers places Hartz's categorical acceptance of liberalism in US history at odds with the pre-World War II Beard view. I extend the Rodgers argument to include the post-Vietnam Zinn egalitarian view. To justify that extension, I assert that the historiographical shift from Beard to Hartz perceived by Rodgers is only part of-but rcpresentative of - a much larger intellectual dialectic in US history.

5. See Wan Vyck Brooks, 'On creating a usable past' in Van Wyck Brooks, the Early' Years: A Selection from His Works, 1908-1925, ed. Claire Sprague Boston: Northeastern Press 1993.

6. See Freyermouth Address, n.d., Roy Emerson Stryker Papers, Reel 1.

7. See Harry Carman, 'An outline of the social and political history of the United States, a syllabus for study classes' New York: Workers Education Bureau of America 1925.

8. Stryker's leadership and vision has been undernined in the work of scholars for almost two decades. See esp., Maren Stange, Symbols of Ideal Life: Social Documentary Photography in America, 1850-1950 Cambridge: Cambridge Univ. Press 1989.

9. For quotation, see Roy E. Stryker interview by F. Jack Hurley, 1967, typescript with ms. corrections. Ned R. McWherter Library, The University of Memphis, Memphis, Tenn,, 15.

10. I have argued elsewhere that this agriculturalism was part of a wider understanding of modernism, that in the search for cultural nationalism, the 1930 s artists found the soul of America to be the farm.

11. For example, an overwhelming majority of the RA/FSA/OWI photographs are now available to the public in digital format on the Library of Congress's 'American Memory' website: http://memory.loc.gov.

12. See Geoffrey L. Buckley and J. Morgan Grove, 'Sowing the seeds of forest conservation: Fed Besley and the Maryland story, 1906-1923' Maryland Historical Magazine 96 (fall 2001), 303-27. It is those authors' opinion that because 'political philosophers like Thomas Jefferson believed that in a largely agrarian society, the private ownership of a farm-individual control of production--would help assure personal liberty, dignity, and economic security for the country's citizens', the US govermment spent the nineteenth century privatizing American land:

Beginning in the eighteenth century, the U.S. government embarked upon a program of transferring land from public to private ownership. By 1900, more than a billion acres of the public domain of half of the land area of the contiguous forty-eight states had been transferred to private hands.... Unfortunately, the conversion of land into private property had many unintended social and ecological consequences. (304).

13. Dorothea Lange and Paul Taylor, An American Exodus: A Record of Human Erosion New York: Reynal \& Hitchcock 1939.

14. Ibid., 136,142

15. Although coined by John Babsone Lane Soule (1815-1891) in an article published by the Terre Haute Express [Indiana] in 1851, Horace Greeley (1811-1872) 'used the expression in an editorial in the New York Tribune, As the saying "Go west, young man, and grow up with the country" gained popularity, Greeley printed Soule's article, to show the source of his inspiration'. See Bartlett's Familiar Quotations, 15th ed. (1882; Boston: Little, Brown, \& Co., 1980), 554; 3, n. 2, entry for John Babsone Lane Soule.

16. Archibald MacLeish, Land of the Free [hereafter LotF] New York: Harcourt, Brace, and Company 1938.

17. The American Dream has been defined since World War II as home (i.e. land) ownership. 'Liberty a famyard wide'-a line from MacLeish's famous America Was Promises - has come to mean a suburban lawn, a two-car garage, and job security, not economic or agrarian self-sufficiency.

18. For the rhetoric of desertification, see Brad Lookingbill, Dust Bowl, U.S.A: Depression America and the Ecological Imagination, 1929-1941 Athens, Ohio: Ohio Univ. Press 2001. See also Donald Worster, Dus Bowl: The Southern Plains in the 1930s London, Oxford Univ. Press 1979.

19. MacLeish, LotF, 87.

20. For James Otis, see MacLeish, 'Night watch in the city of Boston' [1976] in MacLeish, New And Collected Poems, 1917-1976 Boston: Houghton Mifflin Company 1976, 3-6, at 6; for the "aristocracy of wealth and talents' and Thomas Paine, see MacLeish, 'America was promises' [1939] in ibid., 323-31, at 327 and 328, respectively; for Nathaniel Bacon, see MacLeish, 'Nat Bacon's bones' [1933] in ibid., 297-98.

21. A. D. Coleman in the introduction to the 1977 Da Capo edition of Land of the Free refers to MacLeish's voice as 'a collective voice, first person singular'. 'Introduction' in MacLeish, LotF, intro. A. D. Coleman New York: Da Capo 1977.

22. MacLeish, LotF, 80, 83-84.

23. MacLeish's poetry has been examined by at least two environmental historians as signaling Americans' disharmony with the earth and 
the inherent ecologic threat by capitalism (as well as signifying a cultural response to environmental degradation). They are Worster Dust Bowl, 45-48, 63, 66; and Lookingbill, Dust Bowl USA, 34-35. Perhaps we can locate the environmental movement of the New Left earlier than it is traditionally dated; perhaps it belongs to the photographs of dried-up farms and the efforts of those to reach some sort of parity and sanity for the nation's poor and the land they traditionally ran to, but which was no longer there. Perhaps 1930s-era social documentary photography and the cultural production it inspired together were the first post-Progressive envirommental wake-up call. 